\title{
HOWARD ROY SARGENT
}

\author{
$1922-1993$
}

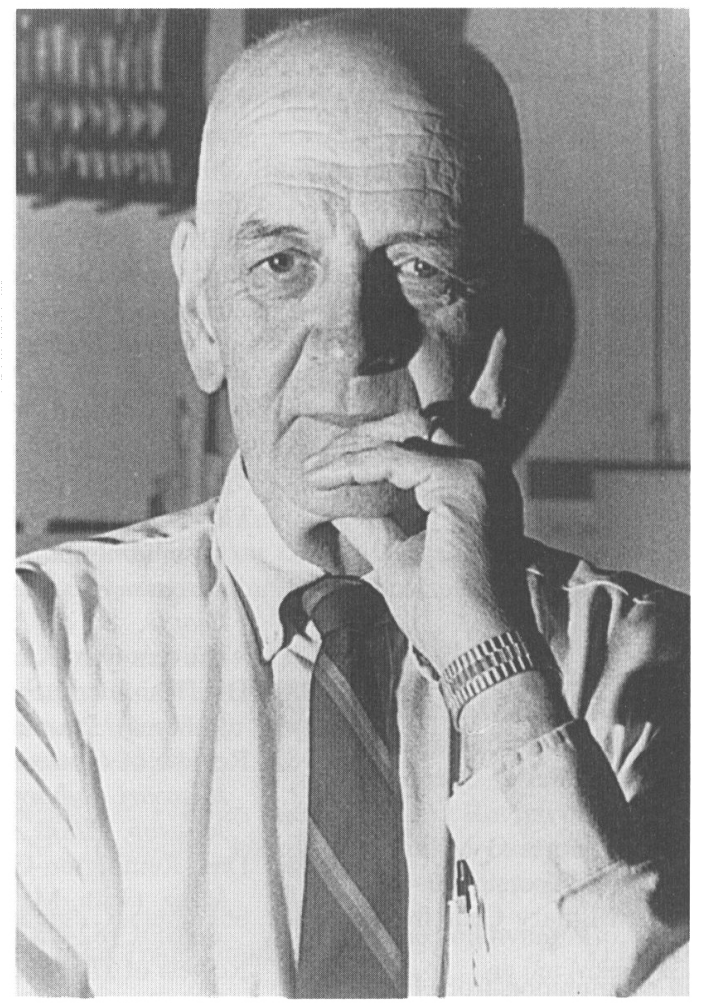

$\mathrm{H}$

oward Roy Sargent was an archaeologist of place. Unlike many other archaeologists whose research takes them far from their home, Sargent's roots in New Hampshire were strong and lovingly nurtured. Over the past four decades, his was perhaps the principal name associated with New Hampshire prehistory. He was also a gifted and highly respected teacher, and the founding editor of the primary archaeology journal of the Northeast, Man in the Northeast (now Northeast Anthropology).

From his early years, Sargent had a long-standing interest in archaeology, Native Americans, and related fields of study that he would develop into a career envied by many. And whether he wanted to or not, Howard could never get completely away from archaeological sites, which turned up whenever he was around. While his interests continued to be broadly defined, several major themes provided a focus for much of his professional work, namely cultural resource management, the archaeology of glacial lake margins, and the prehistory and history of New Hampshire, particularly the Lake Sunapee area.

American Antiquity, 61(1), 1996, pp. 68-71.

Copyright $(\mathcal{O}$ by the Society for American Archaeology 
He was born in Concord, Massachusetts, on September 12, 1922, and spent his early years in eastern Massachusetts, graduating from Littleton High School in 1940. During World War II he served in the Marine Corps, participating in the Okinawa and North China campaigns from 1943 to 1946, from which stemmed his interest in Asian art and archaeology. Following the war, he attended the University of New Mexico Archaeology Field School in 1947. He received a bachelor of arts degree in anthropology from Yale University in 1950, and a master's degree in anthropology from the University of Michigan in 1951. His first professional employment was as archaeologist/park ranger for the North Carolina State Parks from 1953 to 1954.

Sargent was a long-term member of the Society for American Archaeology, and also held life memberships in the New Hampshire Archaeological Society, the Massachusetts Archaeological Society, the National Education Association, and the Royal Anthropological Institute of Great Britain and Ireland. He was a driving force in the development of the New Hampshire Archaeological Society, and served as its president from 1972 to 1973. Beginning in 1950, Howard began the first of his many field archaeology projects in New England, most located in New Hampshire. Some of this early work was conducted under the auspices of the New Hampshire Archaeological Society, the Connecticut Archaeological Society, and the Robert S. Peabody Foundation for Archaeology of Phillips Andover Academy. Howard actively sought out existing artifact collections and published research notes on several. In 1956 he made up 33 display panels of artifacts from the extensive Laurence Crosbie Collection, willed to the Phillips Exeter Academy for public viewing and professional research.

Howard will be remembered foremost as a teacher, and he was a very effective one at all levels. Between 1954 and 1963 he taught in several public school systems in New Hampshire. By 1957 his career as a college instructor in both anthropology and archaeology was already underway-first at Keene State College and then at Lebanon College--and would eventually extend to at least a semester at virtually all postsecondary education institutions in the state. He was the first professor of anthropology at Nathaniel Hawthorne College, and later a dean there. In 1967 Howard joined the Anthropology Department faculty of Franklin Pierce College, which at that time included Edwin S. Dethlefsen and L. Cabot Briggs. Howard taught a variety of anthropology and archaeology classes, and also directed the archaeology field school. He remained at Franklin Pierce College until 1973, at which time he left for a series of short-term appointments at Belknap College, University of Southern Maine, Plymouth State College, Colby-Sawyer College, and the University of New Hampshire. In 1978 Howard returned to Franklin Pierce College, where he remained until 1988, first at the Rindge campus, and subsequently at the Concord campus until the time of his death.

In 1988, Sargent received both the Teacher of the Year Award from the Franklin Pierce College Student Senate and the Franklin Pierce College Alumni Service Award honoring a distinguished career as an educator. He was presented with many other awards and honors throughout his life, including Man of the Year by the Claremont Junior Chamber of Commerce (1958), Leaders in American Science (1968), Who's Who in the East (1971-1973), and the Chester B. Price Memorial Archaeological Award of the New Hampshire Archaeological Society (1971). He was most proud of those that recognized his dual service to archaeology and education.

Howard was also involved as a consulting archaeologist on a variety of mitigative projects in New Hampshire. Before cultural resource management had really developed, Howard directed much of his fieldwork to a variety of historic and prehistoric sites before their destruction, including the Sumner Falls site (1960), the Smyth site (1967), the Hunter site (1967), and the Clement site (1974). Howard's excavation of the Clement site, an unmarked colonial graveyard discovered during trailer park construction, resulted in one of the first physical anthropological studies of colonial New Englanders. The passage of the Moss-Bennett Act and other legislation in the early 1970s helped stem the loss of such sites through the newly established state historic preservation office and various other state agencies. Between 1976 and 1978 Howard served as staff environmentalist/archaeologist for the New Hampshire Water Commission where he oversaw all commission-related projects in the state, including mitigative work at the Weirs Beach site (1976-1977). 
Besides being the founding editor of Man in the Northeast, Sargent served as general editor from 1971 to 1982 . The impetus for the journal was a regional archaeology conference he hosted at Franklin Pierce College in 1970. When the publication of the journal was transferred to the State University of New York at Albany in 1982, he remained the editor for the subsidiary Occasional Publications in Northeast Anthropology (1976-1993). Shortly after Howard's death, the journal was renamed Northeast Anthropology-a change intended to reflect more accurately the growing scope of the journal. The demands of editing the journal and teaching were considerable and often kept Howard from his own writing and research projects, but he remained firm in his commitment to the journal and especially to his students.

His knowledge of New England prehistory was vast, and he was always willing to answer questions from the interested public and the archaeological community. Indeed, anyone beginning an archaeological project in New Hampshire and the surrounding states benefitted from his involvement; those who did not often found that the new site or lithic source they had discovered had been found by Howard years earlier. When Catherine Carlson was researching the Praying Indian Towns of Massachusetts several years ago, she asked him what he knew about the Nashoba Indian Town that was located in his hometown of Littleton. Howard recalled that his father, John A. Sargent, had uncovered human leg bones while excavating the cellar of their home, which had been built in 1673 . His father, then chief of police, sent the bones to Ernest Hooten at Harvard who confirmed they were indeed aboriginal.

Over the last 20 years, Howard spent many seasons excavating prehistoric sites situated around his home on Lake Sunapee, including several located on his brother's property next door. When he decided to dig a foundation as part of an extension to connect his house to his office and lab, not only was a historic dump uncovered, but also a prehistoric site, both of which he duly excavated before proceeding with the addition. Visitors to his home never knew what to expect, and sometimes found themselves with a trowel in one hand and a gin and tonic in the other.

He was a frequent speaker at professional and public functions, and had several popular lecture series: "Backyard Archaeology" and "New Hampshire: The First 10,000 Years," both of which were sponsored by the New Hampshire Humanities Council, and "We Who Greet the Dawn: The Indians of New Hampshire."

Howard's sense of humor knew no bounds. Late risers in the 1971 Hampton Falls field school camp would wake in terror when they found Howard driving toward their tent in the project's Bobcat frontend loader to nudge the support poles--they were the first at breakfast the next day. Field school parties often ended with Howard singing a Lakota war song. He frequently entertained students with humorous stories and reminiscences about well-known archaeologists and anthropologists, providing a welcome respite during lectures on Japanese culture or the history of American archaeology, and also revealing to them some of the human dimensions of the discipline. At one time his answering machine carried the message of Howard shouting, seemingly from a great distance, that he couldn't come to the phone because he was at the bottom of a 5-m-deep excavation unit without a ladder. He was active in several local theater companies, and also starred in two intensely funny Bruce Cronin films, "The Wild Goose" (1973) and "Henry Phipps Goes Skiing" (1976).

Although his publications lacked citations in American Antiquity and other prestigious journals, their value was no less, and many of his early site reports are still frequently referenced. His research focused on virtually all aspects of the cultural and environmental history of the region he knew so well and loved so much, and this orientation proved a very effective teaching device through which he could get his students excited about what was in their own backyard. Thousands of travelers to the Lake Sunapee area were also provided with an overview of its prehistory through his contribution to a popular tourist brochure. Howard's dedication to teaching and to keeping archaeology in the public view is a strategy that has influenced heritage management at all levels in New Hampshire. While some of his students have become professional archaeologists and anthropologists, most went on to other pro- 
fessions where they may, as developers, land-use commissioners, and voters, ultimately have a significant influence on cultural resource preservation. The state of New Hampshire is considering establishing an archaeological museum and research facility in his memory.

Howard Sargent represented that generation of scholars, field archaeologists, and teachers that is responsible for much of the character of contemporary northeastern archaeology. Those of us who learned archaeology from Howard or knew him as both friend and colleague have each been greatly influenced by him, and his absence will continue to be very strongly felt.

Sargent died in New London, New Hampshire, on January 5, 1993, after a brief illness. He is survived by his wife and long-time collaborator, Evelyn, four children, and six grandchildren.

GeORge P. Nicholas

\section{Selected Bibliography of Howard R. Sargent}

1950 Summary of First Season's Work at Clark's Island. Newsletter of the New Hampshire Archaeological Society 2:1-5.

1952 A Preliminary Report on the Excavations at Grannis Island. Bulletin of the Archaeological Society of Connecticut 26:30-50.

1955 Museums in Our Schools. New Hampshire Educator 35(3):14-21.

1959 The Pickpocket Falls Site. The New Hampshire Archaeologist 9:2-6.

1964 Interlaken Site (NH 29-2). The New Hampshire Archaeologist 13:12.

1968 Review of Japanese Rural Society, by Tadashi Fukutake. Man, the Journal of the Royal Anthropological Society 3:343.

1969 Prehistory of the Upper Connecticut Valley. In An Introduction to the Archaeology and History of the Connecticut River Valley Indians, edited by W. R. Young, pp. 28-32. Springfield Museum of Science, Springfield, Massachusetts.
1971 The Prehistory of the Upper Connecticut Valley. Bulletin of the New Hampshire Archaeological Society 16:16-17.

1972 Review of Onondaga Iroquois Prehistory: A Study in Settlement Archaeology, by James Tuck. Man in the Northeast 3:61-62.

1973 (with Francois Ledoux) Two Fluted Points from New England. Man in the Northeast 5:67-68.

1975 Preservation History: The Archaeological Record. The New Hampshire Archaeologist 18:18-23.

1977 The Clement Site: Field Investigation. Man in the Northeast 13:79-85.

1988 Review of Stone Age Spear and Arrow Points of the Midcontinental and Eastern United States: A Modern Survey and Reference, by Noel D. Justice. Science Books and Films 24(2):78. American Association for the Advancement of Science.

1989 The Contoocook River Valley: A Prehistoric and Early Historic Perspective. In A Pictorial History of Bennington, New Hampshire. Bennington Historical Society, Bennington, Vermont. 